\title{
Indian Jute in Australian Museum Collections: Forgetting and Recollecting Transnational Networks
}

\author{
ANDREW HASSAM
}

$\mathrm{F}$ or over 150 years from the late 1820s, Indian jute sacking played an essential role in all areas of life in Australia. Yet its contribution to Australian development and its Indian origins have been barely recognised in Australian museum collections. ${ }^{1}$ Until comparatively recently, Australian wool, wheat and sugar were shipped to the four corners of the globe packed in jute sacks. Domestically, rugs and mats were backed with jute textile and women made aprons and peg bags from the jute sacks in which they bought their sugar and flour. And when the men went to war, they sheltered behind jute sandbags, hid under jute camouflage nets, received their mail in jute mail bags and were buried in jute shrouds. Iconic images of Australia - of wool drays, Gallipoli and Coolgardie safes - reveal the ubiquity of Indian jute in 
Australia, while at the same time they demonstrate its invisibility. Who notices jute?

Occasionally, jute sacks emerge from invisibility, as in 2009 when it was reported that sacks used to transport asbestos had been re-used to carry agricultural fertilizer or pulped to make carpet under felt. As a result of breathing asbestos fibres released from the recycled sacks, a number of people died of mesothelioma, the 'trail of death' enveloping Western Australian wheat farms, Queensland banana plantations, Victorian fruit markets, home renovators and children who ran sack races. ${ }^{2}$ The focus in such a story is naturally on the Australian raw asbestos rather than on the Indian jute sacks that distributed the deadly fibres so widely. But this, of course, highlights the main reason for the invisibility of jute sacking. As packaging, it is secondary to whatever it contains.

As the spread of mesothelioma demonstrates, Indian jute sacking can reveal connections that might otherwise go unnoticed. Jute packaging not only aids the movement of goods; it allows us to explore the ways in which places are physically connected by trade, such as the trading networks that spread asbestos throughout Australia. Though the contaminated sacks seem to have been restricted to Australia, Indian jute passes invisibly through national borders. In the nineteenth century, not only did jute sacks carry Australian wool, wheat and sugar overseas, they also carried rice, cotton and coffee into Australia. Jute sacks connected continents, linking the shearing sheds of South Australia and the sugar mills of Queensland with South Asia, North and South America and Europe.

Online museum catalogues reveal the near complete absence of Indian jute sacks in Australian collections, for which there are various explanations, ranging from the rapid decomposition of jute to jute's lack of visual appeal. But while few sacks have been preserved, the catalogues contain numerous examples of jute being used in the production of other preserved objects such as a Coolgardie safe in Western Australia, a camel saddle in South Australia, an iron house in Victoria and a convict isolation mask in Tasmania. Discovering the extent of such objects depends on the quality of the online catalogues. Presently the number of museum collections with online catalogues is limited and the catalogues themselves are only partially online, factors which skew searches in favour of the Powerhouse Museum's formidable online catalogue. Even so, online museum catalogues do allow us to perceive new relationships and to ask new questions. Where the old card catalogues sought to relate objects using a standard or agreed set of 
subject terms, lack of a standard structure for how information on the web is linked can produce unexpected results, such as the incidence of jute sacks in Australian artworks, as in Evert Ploeg's portrait of Deborah Mailman (1999, National Portrait Gallery) painted on wool sacks and Rosalie Gascoigne's framed Thorpdale potato sack, Pink Kookaburras (1984). The results from online searches may not be as ordered and coherent as those from a museum catalogue. But the tangled web of the internet corresponds to the disordered and incoherent nature of the connections between different instances of jute. There is a methodological parallel between attempts to make sense of the results of online searches and attempts to interpret the interrelationships revealed by the circulation of jute as it roams through the trading networks of the nineteenth-century global economy. In both enterprises, the methodology has to allow for a degree of serendipity, particularly when tracing such a ubiquitous yet invisible commodity as Indian jute.

\section{FORGETTING JUTE}

In a summary of Indian trade for the year 1881-82, the London Times highlighted the increase in the value of trade between India and Australia, despite a lack of regular, direct shipping between the two countries. According to The Times: the 'exports of Indian produce to Australia show a gratifying advance of over 50 per cent on the previous year's figures, gunny bags, tea, castor oil, and rice being the chief articles. The first-named are extensively used for the colonial wool trade, and more than 75 per cent of the whole Indian export trade in these bags is absorbed by Australia'. ${ }^{3}$ The gunny bags which lay at the heart of Indian exports to Australia were woven from jute fibre, a raw material cultivated then, as now, on family-run smallholdings in the Ganges delta. Its economic significance to Australia derived from the cheapness of jute sacking and hessian cloth as a packaging material, especially for bagging wool, wheat and sugar.

Jute yarn had been woven on hand looms in Bengal for centuries before the arrival of the British. ${ }^{4}$ Gunnies early became a staple component of trade between Calcutta and the new settlements of Sydney and Hobart Town. In August 1838, for example, the cargo of the brig Arethusa arriving in Sydney from Calcutta included two bales of sacks and three of sacking, together with bales of raw jute, twine, yarn and cordage. The 1162 bags of sugar and 300 bags of rice that were also on board would have been packed in Indian jute sacks. ${ }^{5}$ In May 1840, the barque Eamont shipped to Hobart 30 bales of gunny bags, 15 bales of gunny sacks, 38 bales of gunny cloth and 111 bales of raw jute. ${ }^{6}$ In 1850- 
51, Calcutta exported over 9 million hand-made jute sacks in total. ${ }^{7}$ The international demand for agricultural commodities such as sugar, grain and wool spurred not only an increase in world production but the demand for bags in which to transport the produce. ${ }^{8}$ In the second half of the nineteenth century and with the aid of power looms, British entrepreneurs, first in Dundee and later in Calcutta, developed cheap jute sacking and hessian cloth into the standard packing and wrapping material of international trade. Calcutta exported around 45.5 million gunnies in 1882, some 12 million to Australia, ${ }^{9}$ the total exported rising to 109 million in $1889 .{ }^{10}$ Indian jute sacks, spun, woven and stitched in the textile mills of Calcutta, were used to transport global commodities such as American cotton, Brazilian coffee, Caribbean sugar and Australian wool and wheat. ${ }^{11}$

Given the importance of India's 'golden fibre' to the economic development and, ultimately, the viability of the colonial settlements of Australia, there is a curious lack of historical awareness of the way in which India and Australia were linked by jute. Jute is not mentioned at all in James Broadbent's India, China, Australia: Trade and Society, 1788$1850,{ }^{12}$ a book which accompanied an exhibition at the Museum of Sydney in 2003. If we look to major Australian museums to stimulate historical understanding, there is only one brief acknowledgment of the role of the Indian jute industry in Australia's history. Museum collections hold many objects incorporating jute cloth but it is disregarded because the jute is generally hidden as upholstery webbing, the lining in footwear or on the underside of rugs. The National Museum of Australia (NMA) holds a handmade rug with a sack base bearing the name of the Colonial Sugar Refining Co. Even where jute is on show, as in the 1950s Red Indian costume held in Museum Victoria (MV) that is also made from Colonial Sugar Refining Co. sacks, it is the object that is on display rather than the jute. Jute is seen everywhere while at the same time remaining culturally invisible.

In terms of sacks, the Powerhouse Museum (PM) holds a jute gunny dating from the early 1990s in which a roll of hand-woven Indian textiles was imported. The museum database instructively notes its Indian provenance: 'Gunny bags like this one are used to package and transport rolls of Indian export textiles. This type of wrapping has been used for bolts of Indian textiles at least since the days of the East India Companies, and possibly much longer given the antiquity of the trade in Indian textiles'. ${ }^{13}$ The bag, however, is incidental to the museum's collection of Indian cotton fabrics and the museum apparently holds no example of the millions of jute gunnies landed annually in Sydney for 
over a century. The NMA holds two jute wool packs, four hessian sacks and a small hessian sugar bag, all items dating from the twentieth century, though, unlike the PM, the NMA database makes no mention of the link between jute and India. Instead, wool packs are deemed significant because they contributed to a wool industry that was important to Australian economic, social and symbolic history. ${ }^{14}$ The only jute collection dating from the nineteenth century is that of MV, which holds samples of Indian jute sacking, bagging, cloth and rope donated in the 1880s, part of a collection of around 1500 samples of the economic products of India from the same period which has only recently begun to interest researchers. ${ }^{15}$

There are numerous material explanations for this absence of Indian jute sacks from major Australian collections. Jute readily breaks down when exposed to moisture and sunlight and, without some form of preservation, all nineteenth-century jute gunnies imported into Australia would by now have perished. Bags and sacks are ephemera, reusable once emptied and discarded when no longer reusable. Jute cloth was ubiquitous, the cheapest packaging material available, and jute had no aesthetic value. Coarsely spun jute fibre was rough to the touch and the cloth lacked visual appeal. Jute, or hessian, was considered fit only for kitchen aprons or as rough and ready protective clothing for workmen, such as the baker's mittens made from gunnies held by the NMA or the hessian shearer's boots in MV. It was found in the home in the form of food sacks, as the backcloth for rugs and in upholstery, but it was associated with poverty because its ubiquity made it available to poorer households as coverings for floors, ceilings, walls and, on occasion, as clothing. Floor coverings, protective clothing and furnishing from poorer households were not deemed worth preserving and, once worn out, jute sacking had neither monetary nor symbolic value to save it from being discarded.

Nevertheless, the limited lifespan of jute fibre does not in itself account for the absence of jute gunnies from collections. The PM holds examples of equally ephemeral objects, such as toilet rolls, cigarettes and bus tickets. There are museums of packaging in London and Heidelberg and, as Carol Breckenridge points out, it is now a commonplace that museum displays transform everyday articles into objects of fascination through what she terms the 'spectacle of the ocular'. ${ }^{16}$ As Sharon Macdonald puts it, objects gain a symbolic value by being removed from the sphere of trade. ${ }^{17}$ The British Museum holds a jute sack that had been used as a cover for a rickshaw seat in Dhaka, Bangladesh, in the 1980s.

Anthropologist Octave Debary has argued that heritage sites and museums contain at their heart a 'willful amnesia' and that collecting 
objects involves not simply a memorialisation of the past but also a process of forgetting. ${ }^{18}$ Debary has a specific example in mind, the museum in the industrial town of Le Creusot in France. In 1970, when the Château de la Verrerie in Le Creusot, the home of the Schneider industrial dynasty, passed into the hands of the municipality, the lack of a collection on which to base a museum was filled by what became a radical version of the ecomuseum, a community-based project focused on the local urban population. In the 1980s, however, the local heavy industry collapsed and the ecomuseum project gave way to a more recognisable museum, with the château today displaying crystal glassware, clocks and furniture belonging to the Schneiders. ${ }^{19}$ For Debary, the ecomuseum project was a kind of ritual re-enactment or mourning of the demise of the local industry and the politics of class conflict: 'Memories turn into images and can be contemplated like curios, cultural - perhaps even touristic - daydreams ${ }^{\prime 20}$ The twenty-five years from the establishment of the ecomuseum project to the return of the Schneider's belongings to the château was needed for the past to be forgotten: 'The passing of a generation was therefore necessary before history could select the objects it wanted to exhibit for all eternity' ${ }^{21}$

Debary is not so much interested in criticising heritage sites for sanitising the past as suggesting, from the perspective of an anthropologist, that objects exhibited in museums are the outcome of a period of collective mourning for past lived experience. However, while the passing of a generation might be necessary for present experience to be reduced to history, a process of selection occurs in which aspects of past lived experience are forgotten, particularly those aspects involving human suffering. Removing the lives of the working people of Le Creusot from the Château de la Verrerie and re-inserting the lives of the Schneiders through their belongings demonstrates not only that presenting human experience through objects is impossible, but also that the reification of the past involves a process of forgetting.

Perhaps, therefore, the absence of jute from Australian collections results from a similar 'wilful amnesia' and process of forgetting. While there are many reasons why jute gunnies have not been preserved, their linking of Australia with India, their importance to the economic development of Australia and their ubiquity in the arduous everyday lives of both urban and rural populations has been forgotten by the major Australian collecting institutions. How have the thousands of millions of gunnies imported into Australia in the century after 1850 disappeared leaving so little trace in representations of the past? Or, following Debary, if the representation of the past as history requires a 
process of forgetting, what has Australian history gained by erasing Indian jute from public memory?

\section{RECOLLECTING JUte}

The development of the heritage industry, of which the Le Creusot Ecomuseum was part, has in Australia, as elsewhere, tended to reduce once vibrant communities to the 'tourist daydream' of the enviable residence filled with fine antiques, while at the same time forgetting the lived experiences of earlier generations of working people. However, the development of the so-called new museology in the 1990s, with its concern for the social context of both museums and their collections, has reminded curators of the significance of the lives and experiences of those outside the social élite and the need to place exhibits within a social framework. For example, the PM and the NMA hold several common kitchen items from the 1930s and 1940s that have been hand made from hessian, such as aprons, peg bags and a tea towel. As museum objects, their value lies in their vernacular designs and in the individual ways in which sacking has been transformed into attractive household objects - the embroidered apron and the peg bag in the shape of a child's dress.

Yet as reminders of how women brightened their lives when more cheerful and finer textiles were not affordable or available, they erase the ubiquity of the hessian from which they have been made. While sacks are discarded, aprons and peg bags are kept for personal reasons, perhaps because they were made by a parent. A sense of loss makes them precious, regardless of their material value. However, Debary goes further and suggests that memory is the outcome of a period of mourning, a period in which some of the more painful experiences and objects associated with them are erased from consciousness: it is not just a question of what is retained, but of what is forgotten in order to retain. If we follow Debary further, the passing of a whole generation may be needed for history to select the objects it wants to forget and those it wishes to exhibit. In this way, common household items such as an apron or a peg bag are selected for public memory by succeeding generations, detached from, and independent of, the meaning for those who used them.

Household objects can emerge from their period of mourning with a national dimension. The Coolgardie safe, for example, was developed in the Coolgardie mining area of Western Australia in the 1890s as a device for preserving fresh food. It became commonplace in Australian kitchens before the coming of electric fridges in the 1950s. The cooling effect was 
produced by evaporation from soaked hessian draped over a frame and there are a number of Coolgardie safes in major Australian collections, including MV and the PM, though the majority take pride of place in regional and town museums, like the Kalgoorlie Mining Museum. The process of honing their memory can be witnessed in 'Coolgardie Safe', a poem by Nicola Knox published in 2001. The poem begins:

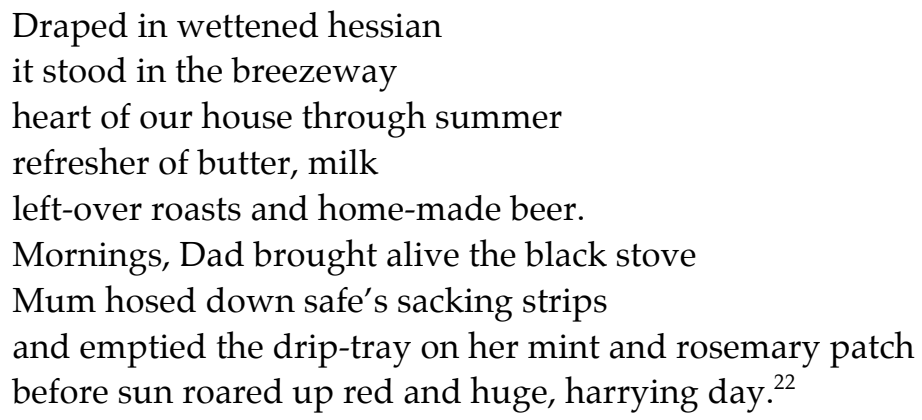

The poem selects aspects of childhood as a way of reifying the loss of childhood, creating a memory poem to be shared by others. The Coolgardie safe in the museum, with its covering of Indian jute sacking, reinforces public memory in a similar way, with both the safe and the childhood being regarded as distinctively Australian.

Empty jute sacks have rarely been invested with public memory in Australia, though they have been elsewhere, as in recollections of hoppicking in England. For almost a century, tens of thousands of workingclass families travelled by train from London to spend September picking hops in the Home Counties, particularly Kent, where, according to a newspaper report from 1937, the hop-pickers absorbed the terminology of hop production: 'I found the pickers using many terms that I had to have interpreted. A "poke", for instance, is a bag in which the hops are taken to the drying kilns, where they are purified by sulphur fumes and dried. There they are hand-pressed into "pockets" (larger and stronger sacks) and are then ready for the brewers' ${ }^{23}$ Each family of hop-pickers tipped their hops into jute sacks of varying shapes and sizes depending on their function and recollections of hop-picking resonate with hessian 'pokes', 'pockets' and 'cribs'. Indeed, the smell of jute itself becomes a memory that is at once both personal and communal: 'We were all given Hessian sacks to sleep on, sacks that had once contained god knows what, but to this day I can still smell it'. ${ }^{24}$

The jute sacks into which cotton was picked in the American South were given various local names - 'pick sacks', 'tow sacks' or 'crocus sacks' - and, as with the English hop-pickers, the names appear in 
recollections of the 1930s: 'Step one was to pick cotton-you needed a pick sack. These was [sic] sold in stores. They were made of burlap or heavy cloth and usually measured about six feet long. ${ }^{25}$ Slave narratives speak of African-American cotton workers wearing hessian clothing and sleeping on hessian mattresses under hessian blankets and, while gunnies might also have been made of hemp and clothes fashioned from calico or flax, the sight, smell and feel of Indian jute would have been as familiar to the cotton-pickers of the American South as they were to the hop-pickers of England. Each bale of cotton was wrapped in about six yards of jute cloth, the annual crop requiring an estimated 100 million yards. ${ }^{26}$ Variations in the size of American agricultural harvests directly influenced the annual Indian jute textile output.

Slave workers on the British sugar plantations in the Caribbean were similarly surrounded by the sight and smell of jute sacking. The presentday colonial resonances of hessian, or burlap, are one of the reasons Jamaican artist, Yasmin Spiro, gives for using it in her installations:

Burlap... is symbolic in several ways. It was used to pack sugar cane for export during slavery - it's still used for this purpose - and thus suggests moral and commercial exploitation as well as Jamaica's historical subservience to foreign economies. Further, the biblical sackcloth symbolizes death and deep mourning. But it is also an organic chrysalis, a biodegradable material used in farming to contain and protect roots. Finally - and perhaps most important to me - it is a vernacular, yet expressive and resilient material. ${ }^{27}$

Spiro finds value in the resilience of the vernacular and, like the Coolgardie safe, the jute sack is invested with both personal and collective memory, memorialising the lives of past generations.

Few jute sacks have been preserved beyond the odd hop pockets exhibited in local tourist attractions like Kent Life or the pick sacks in regional cotton museums in the USA. ${ }^{28}$ Where they have been preserved it is because they are invested with memories of a collective way of life. As Sharon Macdonald has noted, it was the small, local museums, rather than the major national museums, that, towards the end of the twentieth century, actively sought to preserve the vernacular: 'such museums mostly collected and displayed the material culture of the everyday and more recent past, especially that of working-class and minority communities'.$^{29}$ Very few major Australian museums hold jute sacks but, where they do, the sacks have most likely been acquired as part of a 
small, community collection. The English hop sack in the PM, for example, was acquired when the PM absorbed the Sydney museum of Tooth's Kent Brewery in the 1980s. ${ }^{30}$

Macdonald argues that local museums collect and display material culture 'as a means of reinforcing and giving legitimacy to group and place-based identities', ${ }^{31}$ but vernacular objects do not bring an innate meaning to local museums. For Macdonald, everyday objects come to local museums 'after a previous life of regular use', the wear and tear 'telling me, if I had the will to listen imaginatively, about what it had lived through'. ${ }^{32}$ But the object is a 'witness', in Macdonald's terms, only through the viewer's knowledge of the types of narrative that the object seems to tell. Such objects are meaningful only to the extent they are consistent with the stories of everyday life that already underpin community identity. The 70lb Colonial Sugar Refining Company sugar sack in the Hurstville City Museum and Gallery, NSW, is associated with the restored Centennial Bakery Building in Hurstville. The sack owes its preservation to a community identity that can be told in the form of recollections, such as the story of Syd Packham and Packham's Bakery. ${ }^{33}$ It is, therefore, a sense that the objects are, or may be, recalled collectively by succeeding generations that invests vernacular objects with the power to reinforce group identities and leads to their preservation. Unlike crystal glassware, jute sacks need to play a role in a communal memory to survive.

\section{JUTE AND AUSTRALIAN SUGAR}

A primary aim of the Verdant Works jute museum in Dundee is the intergenerational perpetuation of cultural memories. The Dundee jute mills, superseded by Calcutta during the First World War, ${ }^{34}$ went into a long decline, with the Cox Brothers' Camperdown Works, at one time synonymous with Dundee, closing in 1981. In the 1990s, however, there was sufficient historical interest in Dundee's jute industry to prompt the conversion of a derelict mill, Verdant Works, into a jute museum. Unlike in Australia, the museum acknowledges the role of India in the production of jute textiles and, according to its promotional leaflet: 'Verdant Works follows the journey of jute, from the fields of the Indian sub-continent to the mills of Dundee, and then on to the four corners of the world ${ }^{35}$ Nonetheless, the primary aim of the Verdant Works museum is understandably to develop historical awareness of the conditions in which the bulk of Dundee's inhabitants lived and worked and multimedia activities, interactive displays and audio visual aimed at 
children 'bring the past alive': 'Feel what it was like to toil in the noise, dust and danger of the mills'. ${ }^{36}$

Australia has no jute industry to recall and 'bring alive' and attempts to establish jute works in Australia seem to have been shortlived. In 1880, the Otago Witness reported the closure of McPherson's, one of Melbourne's two jute mills, ${ }^{37}$ which had been set up just five years earlier by a successful Scottish iron merchant, Thomas McPherson. ${ }^{38}$ The jute factory, which was situated on the banks of the River Yarra in Footscray, would have produced wool packs, sacks for locally processed flour, sugar, fertiliser and rope and twine for ships. But it seems to have been forced to close due, ironically, to a protectionist tax on wool packs and wheat sacks. ${ }^{39}$ Redevelopment of the site has left no trace of the jute works and its historical significance stems from the later Edwardian motor tyre factory. ${ }^{40}$ The other jute mill was presumably that of the appropriately named James Miller, another Scot, who had established a mill to weave wool and wheat sacks in South Melbourne in $1874 .{ }^{41}$ However, Miller sold the site for redevelopment in 1890 and, unlike the UK, Australia lacks any heritage buildings associated with jute.

Australia does, though, have regional museums dedicated to some of the commodities that were transported in jute sacks, such as Kwinana Granary Museum in Western Australia or the Australian Sugar Industry Museum at Mourilyan in North Queensland. As with the sacks in hop and cotton museums that are preserved because they substantiate a communal memory, so a Millaquin sugar bag is displayed at the Mourilyan museum because it appears in recollections of everyday life: 'the multi-adaptable sugar bag that became a welcome mat to wipe off the tropical mud, a carpet, curtains, a mattress or a shopping bag' ${ }^{42}$ According to a review of the sugar museum, visitors 'are especially drawn to the collection of items, domestic and farming, that were part of the lives of the workers who created the successful sugar economy' ${ }^{43}$ As one travel guide puts it using the discourse of the heritage museum: 'Experience the drama and heritage of Australia's sugar industry' ${ }^{44}$ The sugar museum owes much to its former director, John Waldron, who, from 1998 to 2004 - when the sugar industry withdrew funding initiated major projects and touring exhibitions, such as the oral history project, Sweet Talking, that shifted the museum's focus from sugar technology to people's lives. ${ }^{45}$

The Mourilyan museum is one of a number of sugar museums, such as the Alexander and Baldwin Sugar Museum in Hawaii, the Redpath Sugar Museum in Toronto and the Mauritius Sugar Museum, that, as industrial museums, develop the association between their location and a particular trade or industry. The primary focus of many industrial 
museums is the product and the technology of production, as with the Sugar Machinery Museum in Barbados and, indeed, the Jute Museum in Kolkata. More recently, however, industrial museums like the Verdant Works jute museum in Dundee and the Mourilyan sugar museum have focussed less on the technology and more on the lives of the producers, their physical environment and their social and cultural values. This trend is compatible with the call by the former director of the Henry Ford Museum, Harold Skramstad, for 'content-rich experiences' that connect to the lives of museum visitors: 'People don't read very well standing up, and every study of outcomes of museum experiences tells us that people remember almost nothing of the content. That same research, however, reminds us that they do remember experiences and things that they are able to connect to their own lives and experience' ${ }^{46}$

There is, however, a danger in local museums collecting and displaying material culture, in Macdonald's words, 'as a means of reinforcing and giving legitimacy to group and place-based identities ${ }^{\prime 47}$ where place-based identities exclude the connections between groups of people living in different places. Where an object, such as a jute sack, is used to substantiate the recollections of a particular area, the connections that object has with the stories of other communities in other places is disregarded. The hop sack in the Kent Brewery in Sydney meant something different to an Australian brewery worker than to an English agricultural worker on the Hole Park estate in Kent where the same sack was filled with hops and something different again to the Bengalis or Dundonians who wove the sacking. Yet all of them were touched by the jute sacks on which the trading networks of the nineteenth-century global economy depended.

If Indian jute sacks substantiate the lived experience of those who worked with them, they also illustrate collectivities, like socio-economic class - in the case of the hop-pickers or brewery workers - or race - in the case of slavery - or even gender - in the case of jute clothing - that extend beyond the immediate locale. Indeed, despite the imputed Australianness of the Coolgardie safe, these collectivities extend well beyond the nation. The transnationalism of those who filled, transported and emptied Indian jute sacks is not the self-conscious cosmopolitanism of an industrial dynasty such as the Schneider family; it is the cosmopolitanism of the invisible and mostly unconscious interrelationship between all those whose labour sustained a global trading economy.

In 2007, the Museum of London Docklands, itself housed in a former sugar warehouse in the West India Docks, opened a permanent 
exhibition, 'London, Sugar and Slavery'. It exposed the transnational political, economic and cultural links that have been hidden by the development of a British, place-based identity. In the words of the exhibition's press pack:

What is London's dirty big secret? What does a sweet cuppa have to do with a terrible crime against humanity? What product links millions of enslaved Africans and London's Dockers? How did English ladies and freedom fighters in the Caribbean find themselves united in struggle? Who really led the abolition campaign for the transatlantic slave trade? And what price freedom? $?^{48}$

In seeking to raise historical awareness of the political, social and cultural consequences of the sugar trade, the exhibition is less about the properties of sugar and the technology of sugar production, as it might be in a more conventional trade museum, than about the interrelated human consequences of the taste for drinking sweetened coffee that developed in England in the eighteenth century. Of course, recognition of the connection between the London sugar trade in the eighteenth century and the Londoners today who are descended from the African slaves who worked the British sugar plantations in the Caribbean gives, in Macdonald's terms, legitimacy to group and place-based identities, such as a British West Indian or a broader multi-ethnic London identity. Nonetheless, 'London, Sugar and Slavery' demonstrates how a local heritage site, such as a sugar warehouse, offering almost 200 years of placed-based recollections, is able to explore transnational economic, political and cultural relationships, deconstructing imperialism to avoid the temptation of presenting the story of sugar through a simplistic opposition between reified British and West Indian identities.

In 2001, the Australian Sugar Industry Museum at Mourilyan mounted what might seem to be a similar exhibition. The exhibition, called Refined White, aimed to highlight the contribution made by South Sea Islanders to the cane-field communities of Queensland through the use of display boards, artefacts, photographs and sound recordings. However, a review of the exhibition suggests there was a mismatch between the text, which presented the Islanders as victims of an Australian slave trade, and the photographs, which were of proud and defiant individuals. The reviewers concluded that this mismatch was the result of weak liaison between local communities, historians and curators. ${ }^{49}$ But the exhibition's aims seem also to have been undermined 
by the attempt of a self-styled Australian museum to speak on behalf of the nation. Rather than deconstructing Australian imperialism as a way of exploring connections, it presented the past through the prism of an Australian national identity, one in which cultural identity is constructed through the exclusion or enclosure of cultures that are regarded as different from the dominant, white society. Or to put it another way, if one uses material culture to reinforce the idea of an exclusionist national identity, it is difficult to use the same material to reinforce the idea of the transnational interrelatedness of distant communities that have been touched by imperialism.

\section{JUTE AND AUSTRALIAN WOOL}

If it is hard not to view the sugar industry through the prism of an Australian national identity, how much harder would this be in the case of wool, the most axiomatically Australian of Australia's primary industries with its symbolism of jumbucks, kelpies and shearing sheds. In the nineteenth century, teams of horses or bullocks hauling loaded wool drays through a wild-looking Australian landscape were a popular subject with both painters and their viewing publics, and a number of works are held by major Australian galleries, ranging chronologically from George Fairholme's sketches of wool teams in the 1840s (National Gallery of Australia), through reproductions of S. T. Gill's watercolour of the wool dray (National Gallery of Australia; National Library of Australia), to the oils of the 1880s and 1890s, such as Edward Roper's Bringing Down the Wool from a Murray Station (National Library of Australia) and George Lambert's Across the Black Soil Plains (Art Gallery of NSW). More numerous still are the hundreds of photographs from the 1880s and 1890s showing wool being pressed into bales and taken by wagon to a rail depot or wharf to be transported to the cities and then shipped overseas. These photographs not only document the process of transporting wool from outback shearing sheds but they also reflect the value attached to the wool industry and to the men and beasts upon whom the industry depended. As a saying from the 1930s put it, Australian prosperity rode on the sheep's back.

All of these paintings and photographs include wool sacks that were made from jute grown and woven in India. Therefore, the Australian collection seemingly most likely to contain Indian gunnies is the National Wool Museum, housed in a restored nineteenth-century wool store on the waterfront in Geelong, about 50 miles from Melbourne. The two main galleries are structured around the technology of sheep farming ('visitors can follow the path of the fleece through shearing, 
classing, wool pressing and dispatch') and wool processing ('A sequential display of the machinery actually used in the process demonstrates the transformation of fleece to fabric' $).{ }^{50}$ In addition to the technology, however, the museum claims to display the 'human effort' required by sheep farming and offers 'an insight into the people... involved in the textile industry'. ${ }^{51}$ To that extent its reconstructed mill worker's house reflects the shift in the focus of museums from product to producer. But in styling itself the National Wool Museum, Geelong's regional museum of wool underplays both regional and transnational dynamics in favour of a static 'timeless Australian story of wool' ${ }^{52}$ This claim relies on radical nationalism's claim that unique Australian cultural values were generated in the shearing sheds of the late nineteenth century. Styling the museum a national museum may well have been a marketing choice, but, as with the self-styled Australian Sugar Museum at Mourilyan, it burdens a provincial museum with the patriotic need to articulate a triumphant nationalism. In attempting to speak on behalf of the nation, the public museum denies more multidimensional models of cultural identity that are less linear and less place-based. The 'timeless Australian story of wool' has, in fact, no time for the dependence of the wool industry on jute sacks produced in India and, while wool was woven into an Australian national consciousness, Indian jute was not.

This is not to say that jute sacks have been erased entirely by the development of an Australian national consciousness and a jute wool sack is endowed with an indigenous Australian identity in Antony Hamilton's 1984 sculpture, 'Raddle' (Art Gallery of South Australia). 'Raddle' is comprised of found objects, the largest of which is a wool sack that has been folded several times. Resting on top are two bale hooks, both bound in jute fabric, and the whole is coloured reddishbrown by the application of raddle, coloured chalk used to mark wool bales and sheep. ${ }^{53}$ The sack and hooks were apparently collected by Hamilton during a spell working in outback South Australia and, according to the notes supplied by the gallery, the everyday objects 'have the capacity to evoke memories or to offer reminders of the enduring mythologies of the Australian bush' ${ }^{54}$ While the objects are undoubtedly evocative, the memories and 'enduring mythologies' they are held to sustain are those of the nation rather than any South Australian community, a nation looking back, perhaps nostalgically, to 'the glory days of the sheep industry'. Moreover, as archaeological artefacts, the sack and the hooks become invested with a quasiindigenous metaphysics, the raddle explicitly mimicking the use of ochre in Aboriginal culture. As the notes put it: 'Hamilton has rescued a few 
telling objects from a dusty death in an unseen corner of a local history museum to re-present them in "Raddle" as some kind of sacred objects laid out as if for a special ceremony'. However, the claim here for the superiority of the art gallery over the local history museum is misplaced if it suggests that place is transcended by ordering objects rather than by allowing them to remain disordered and open to serendipity. Finding the components of the work may have been serendipitous. But from another perspective, the artwork itself comes to seem like a dusty museum display, dead, 'laid out', the sack and hooks the remnants of a more glorious past.

In her discussion of the permanent exhibitions in the Transcultural Galleries at Cartwright Hall in Bradford, West Yorkshire, Sharon Macdonald makes the case that freeing up the sense of order normally found in galleries allows space for new perspectives, both visually and conceptually. 'Rather than this working by a logic of distinction and taxonomic categories', she notes, 'the logic is one of connection' ${ }^{55}$ Macdonald, like the exhibition's curator, Nima Poovaya-Smith, is interested less in those museums and galleries that use material culture to construct and reinforce national identities than in museums and galleries that allow transcultural and, indeed, postnational connections to be made between objects. These connections are not, however, restricted by time and place, or by any fixed viewing position: 'What we have here... is not a notion of connection as somehow "bringing out" some underlying reality... but of connection as serendipitous, suggestive, and sometimes witty and ironic'..$^{56}$

According to Macdonald, the fluidity and plurality of the connections, which stem from the fluidity and plurality of postnational cultural identities, is the result of making the objects, rather than textual explanations of them, the centre of the exhibition: 'The objects exhibited, rather than any particular geographical or ethnic categories are clearly the starting point and main content of the exhibition'. Although the Transcultural Galleries, which opened in 1997, have subsequently been refurbished and renamed, the new name for the exhibition, 'Connect: People, Place, Imagination', reflects the continuing involvement of Nima Poovaya-Smith and the development of her strategies for promoting an awareness of transcultural connections. ${ }^{57}$

Macdonald admits that similar aims and strategies would be more difficult to undertake in history museums where causation is an organising factor and where aesthetics plays less of a role. But it can be noted that the redeveloped Ashmolean Museum of Art and Archaeology in Oxford has adopted a new display strategy, 'Crossing Cultures 
Crossing Time'. It echoes the postnational outlook of Bradford's Cartwright Hall:

Crossing Cultures Crossing Time (CCCT) is an approach based on the idea that civilisations that have shaped our modern societies developed as part of an interrelated world culture, rather than in isolation. It assumes, too, that every object has a story to tell, but these stories can best be uncovered by making appropriate comparisons and connections, tracing the journey of ideas and influences through the centuries and across continents. ${ }^{58}$

The Ashmolean is not burdened with the need to celebrate the nation. Rather than present cultural identities as bounded and coherent in order to construct and reinforce a national identity, exhibitions like those in Bradford and Oxford attempt to make visible an interrelatedness that the territorial logic of nationalism excludes or contains.

If Indian jute is to be acknowledged as part of 'the Australian wool story', the concept of an Australian story must change and wool exhibitions need to explore, rather than ignore, transnational connections. The association of wool production with the development of an Australian nationalism in the 1880s and 1890s hampers exploration of a transcultural history of the wool industry in Australia and awareness that behind the idealisation of masculine labour in Tom Roberts' iconic Shearing the Rams (National Gallery of Victoria) was not only the backbreaking eleven- or twelve-hour day of the pastoral worker in Australia, as Leigh Astbury has argued, ${ }^{59}$ but also the backbreaking labour of Bengalis harvesting jute. George Lambert's similarly heroic image in Across the Black Soil Plains of a team of horses hauling a wagon laden with wool bales equally ignores the labour of those who transported the raw jute to Calcutta and the labour of the mill workers who wove the jute for the wool packs. If Australia's prosperity was built on the sheep's back, it was also built on the backs of Indian men, women and children who laboured to grow and mill jute, and on the backs of the Indian seamen who worked the ships that carried the jute to Australia.

From this perspective, the connection made by the PM's search engine between a woollen kangaroo tea cosy on a hessian backing and a hessian padded camel saddle, though initially serendipitous, suggests that expressions of Australian nationalism - the kangaroo tea cosy depend on transnationalism - the Indian hessian. And if this is the case, then expressions of Australian nationalism also depend on the presence in Australia of hessian padded camel saddles, the camels themselves and 
their South Asian cameleers. Indeed, as recent research by Philip Jones at the South Australian Museum has made clear, South Asian cameleers played a key role in South Australia before the development of the rail system by transporting essential supplies to remote sheep stations and returning with wool. ${ }^{60}$ If attention to Indian jute makes visible the Indian gunnies in nationalist representations of wool drays being hauled by bullocks or horses, it also makes visible the camel teams that enabled Europeans to settle ever further into the Australian continent, settlement on which the very notion of an Australian nation depends.

\section{CONCLUSION}

The 'wilful amnesia' necessary for the construction of a nationalist history involves erasing the ways in which the cultural identities affirmed on sugar or cotton plantations, in hop gardens or in shearing sheds were based less on national sentiment than on place and group affinities. These affinities were interrelated at both sub-national and supra-national levels. If public museums are to revitalise past lived experience in order to engage with lives and experiences today, then they must necessarily make visible what has been erased from the stories we tell ourselves about the past, particularly the erasure of collectivities that extend beyond the borders of the nation-state, such as race, socioeconomic class and gender. Jute's own erasure from public memory makes it an ideal medium through which to summon up a past that, following Debary, has been erased in the process of turning lived experience into national memory.

While museums may be required by those who fund them to represent the lives of local communities, in seeking to increase access by digitising their catalogues and collections, museums connect with multiple global networks and the meanings of objects cannot be contained within the walls of the museum. As Fiona Cameron puts it, 'objects also take on the role of mapping out a public space beyond the museum' ${ }^{61}$ The digitisation of objects shifts interpretation from their relationship to other objects in place-based collections to their relationship to other digitised objects transnationally. Even if such relations and the meanings derived from them cannot be contained by curators, the serendipity of digital searches generates connections that have the potential to deepen historical understanding of transcultural relationships. Searching cyberspace for Indian jute will not reveal the impressive figure of the goddess Durga made entirely from jute fibre that is housed in the un-digitised Indian museum in Kolkata. But it does reveal the work of artists such as the Jamaican, Yasmin Spiro who 
incorporates jute into her work to symbolise the transcultural resistance of the vernacular to colonialism.

The internet offers researchers new tools for examining the history of transcultural networks and new resources for raising historical awareness of transnational ties. How museums might best use these tools and resources needs to be carefully considered because, as Sheila Watson warns, museums that take an instrumental attitude towards history risk unforeseen consequences.$^{62}$ Nonetheless, it is clear that developing an awareness of the contribution of Indian jute to Australian development requires an awareness not simply that jute comes from India but that statements of national identity by collecting institutions depend on a 'wilful amnesia' of transnational connections evident in their own collections. As Debary reminds us, it is not just a question of what has been retained, but of what has been forgotten.

\section{ENDNOTES}

${ }^{1}$ Many terms are used to refer to sacking made from spun jute fibre. Gunnies are sacks made from jute, hemp, flax or other vegetable fibres; gunny bag is tautological, but is in common use. Hessian is technically lighter than jute sacking with a finer weave, though jute sacking can be referred to as hessian, regardless of its weave or weight. In North America, hessian is called burlap, though burlap can also be made from hemp and flax. In this article, gunnies refers to sacks or bags made from jute cloth, including hessian; hessian is used mainly where it appears in an original source and indicates jute textile with a finer weave; burlap is avoided.

2 James Hardie, "'Covers Up" More Asbestos Secrets', 7.30 Report, 24 August 2009 (Online). Available: http:/ / www.abc.net.au/7.30/ content/2009/s2665543.htm (Accessed 30 November 2009).

3 'The Trade of India, 1881-82', Times, 11 January 1883, p3.

4 Tara Sethia, 'The Rise of the Jute Manufacturing Industry in Colonial India: A Global Perspective', Journal of World History, vol 7, no 1, 1996, p73.

5 'Sydney General Trade List', Sydney Gazette and New South Wales Advertiser, 16 August 1838, p4.

6 'Imports', Hobart Town Courier and Van Diemen's Land Gazette, 8 May 1840, p4.

${ }^{7}$ Sethia, op cit, p73.

${ }^{8}$ George Watt, A Dictionary of the Economic Products of India, W. H. Allen And Co, India, vol II (Cabbage to Cyperus), 1889, p546.

${ }^{9}$ ibid, p560.

${ }^{10}$ George Watt, A Dictionary of the Economic Products of India, W. H. Allen And Co, India, vol IV (Gossypium to Lonociera), 1890, p559.

${ }^{11}$ Dundee and the Jute Industry, nd (Online). Available: http:/ / openlearn.open.ac.uk/mod/resource/view.php?id=278519 (Accessed 13 March 2009).

12 James Broadbent, Suzanne Rickard and Margaret Steven, India, China, Australia: Trade and Society, 1788-1850, Historical Houses Trust of NSW, Sydney, 2003.

${ }^{13}$ Gunnybag (sack), 1990-1993, registration number 94/32/6 (Online). Available: http: / / www.powerhousemuseum.com/ collection/database/ ?irn=141379\&search=ascraft\&i mages $=\& c=\& s=$ (Accessed 10 January 2010).

${ }^{14}$ Jute Bale Pack (Online). Available: http://www.nma.gov.au/collectionssearch/display?irn=119832 (Accessed 1 October 2009).

${ }_{15}$ Cherie McKeich, 'Botanical Fortunes: T. N. Mukharji, International Exhibitions, and Trade between India and Australia', in reCollections: Journal of the National Museum of Australia, vol 3, no 1, 2008. Available: http://recollections.nma.gov.au/issues/vol 3 no $1 /$ papers/ (Accessed 5 October 2009).

${ }^{16}$ Carol A. Breckenridge, 'The Aesthetics and Politics of Colonial Collecting: India at World Fairs', Comparative Studies in Society and History, vol 31, no 2, 1989, p196.

17 ibid; Sharon J. Macdonald, 'Museums, National, Postnational and Transcultural Identities', in Museum and Society, vol 1, no 1, 2003, p3. 
${ }^{18}$ Octave Debary, 'Deindustrialization and Museumification: From Exhibited Memory to Forgotten History', Annals of the American Academy of Political and Social Science, vol 595, no 1, $2004, \mathrm{p} 123$.

${ }^{19}$ Creusot-Montceau Ecomuseum (Online), 2006. Available: http:/ / www.ecomusee-creusotmontceau.com/ (Accessed 9 November 2009).

${ }^{20}$ Debary, op cit, p131.

${ }^{21}$ ibid, p130.

${ }^{22}$ Nicola Knox, 'Coolgardie Safe', Hecate, vol 27, no 2, 2001, p111.

${ }^{23}$ Information Sheet no 3: Hop Growing and Hop Picking (June 2001) (Online). Available: http:// www.buriton.org.uk/bhb/infosheet03.htm (Accessed 22 August 2011).

${ }^{24}$ Graham Webb, Hop-Picking, Our Summer Holidays in 1950 (Online), nd. Available: http:// www.forcesstories.com/storydetails.asp?ID=84 (Accessed 22 August 2011).

${ }_{25}$ Cotton Picking, 2009 (Online). Available: http:// fridays-crossing.com/cotton-picking.php (Accessed 29 October 2009).

${ }^{26}$ Gordon T. Stewart, Jute and Empire, Manchester UP, Manchester, 1998, p14.

${ }^{27}$ New Possessions: Jamaican Artists in the US (Online), nd. Available: http://www.museum.oas.org/exhibitions/museum exhibitions/new possessions/image 0 6.html (Accessed 27 October 2009).

${ }_{28}$ Kent Life (Online), nd. Available: http: / / www.kentlife.org.uk (Accessed 22 August 2011).

${ }^{29}$ Sharon Macdonald, 'Collecting Practices', in Sharon Macdonald (ed), A Companion to Museum Studies, Blackwell, Oxford, 2007, pp81-97.

${ }^{30}$ Mary Ann Hamilton and Sue Andersen, An Oral History of Kent Brewery, Carlton \& United Breweries (NSW) Pty Ltd, Sydney, 2004, p26.

${ }^{31}$ Macdonald, 'Collecting Practices', pp81-97.

${ }^{32}$ Sharon Macdonald, 'On "Old Things": The Fetishization of Past in Everyday Life', in Nigel Rapport (ed), British Subjects: an Anthropology of Britain, Berg, New York, 2002, pp89-106.

${ }^{33}$ Syd Packham OAM: An Industry Legend (Online), nd. Available: http://w235.staging.bluearcgroup.com/ upload/files/Syd\%20Packham\%20article.pdf (Accessed 22 November 2009).

${ }^{34}$ Sethia, op cit, p72.

${ }^{35}$ Verdant Works: Weaving Tales of Old Dundee (Online), nd. Available: http://www.tourismleafletsonline.com/pdfs/Verdant Works Jute Museum Leaflet.pdf (Accessed 22 August 2011)

${ }^{36}$ ibid.

37 'The Fallacies of Protection', Otago Witness, 13 March 1880, p7.

${ }^{38}$ McPherson's Ltd, International Directory of Company Histories, vol 66, St. James Press, Detroit, Mich., 2004. Available: http:/ / www.fundinguniverse.com/company-histories/McPhersonsLtd-Company-History.html (Accessed 9 October 2009).

39 'The Fallacies of Protection', Otago Witness, 13 March 1880, p7.

${ }^{40}$ nd, Barnett Glass Rubber-Bradmill (Online). Available: http:/ / vhd.heritage.vic.gov.au/places/result_detail/28419?print=true (Accessed 22 August 2011).

${ }^{41}$ Gary Vines, nd, Rope Making in Victoria (Online). Available: http:// members.ozemail.com.au/ garyhelen/ropemaking.htm (Accessed 18 November 2009).

${ }^{42}$ Jan Lahney, 'The Australian Sugar Industry Museum,' etropic: Electronic Journal of Multidisciplinary Studies in the Tropics, vol 3, no 1, 2004 (Online). Available: http:// www.jcu.edu.au/etropic/ET3-1/LahneySugar.htm (Accessed 19 November 2009). ${ }_{43}$ ibid.

${ }^{44}$ Australian Sugar Industry Museum-Innisfail (Online), 2011. Available: http:// www.agfg.com.au/guide/ qld/tropical-north-qld/athertontableland/innisfail/attractions-tourism/australian-sugar-musuem (Accessed 22 August 2011).

${ }^{45}$ Denise Neville (ed), Sweet Talking: A Collection of Oral Histories from the Australian Sugar Industry, Australian Sugar Industry Museum, Innisfail, Qld, 1998.

${ }^{46}$ Harold Skramstad, 'The Mission of the Industrial Museum in the Postindustrial Age', The Public Historian, vol 22, no 3, 2000, p29.

${ }^{47}$ Macdonald, 'Collecting Practices', pp81-97.

${ }^{48}$ London, Sugar and Slavery: Gallery Reveals City's Untold History (Online), nd. Available: http:/ / www.museumindocklands.org.uk/NR/rdonlyres/C0CD2D0D-1ED3-4187-87CF03DA3014A4DF/0/LSS press pack.pdf (Accessed 22 August 2011).

${ }^{49}$ Max Quanchi and Clive Moore, 'Refined White, Queensland Museum, Brisbane, Regional and Interstate 2001-2002', Journal of Pacific History, vol 37, no 1, 2002, p126. 
${ }^{50}$ Telling the Story of Wool (Online), 2011. Available: http:// www.geelongaustralia.com.au/nwm/about/services/article/8cbcc30a00058a5.aspx (Accessed 22 August 2011)

${ }^{51} \mathrm{ibid}$.

${ }^{52}$ National Wool Museum (Online), 2011. Available:

http:/ / www.geelongaustralia.com.au/nwm/ (Accessed 22 August 2011).

'Raddle', 1984 (Online), 2006. Available: http:/ / www.artgallery.sa.gov.au/TLF/872s1/ (Accessed 22 August 2011)

${ }^{54} \mathrm{ibid}$.

${ }^{55}$ Sharon J. Macdonald, 'Museums, National, Postnational and Transcultural Identities', Museum and Society, vol 1, no 1, 2003, p9.

${ }^{56}$ ibid.

${ }^{57}$ Painting a Brighter Picture with Growing Art Scene', in Yorkshire Post, 28 March 2008. Available: http://www.yorkshirepost.co.uk/art/Painting-a-brighter-picture-with.3925367.jp (Accessed 22 August 2011).

${ }^{58}$ New Display Strategy (Online), 2011. Available: http://ashweb2.ashmus.ox.ac.uk/transforming/newdisplay/ (Accessed 22 August 2011).

${ }^{59}$ Leigh Astbury, City Bushmen: The Heidelberg School and the Rural Mythology, Oxford University Press, Melbourne, 1985, pp102-13.

${ }^{60}$ Philip Jones and Anna Kenny, Australia's Muslim Cameleers: Pioneers of the Inland, 1860s-1930s, Wakefield Press, Adelaide, 2007.

${ }^{61}$ Fiona Cameron, 'Object-oriented Democracies: Conceptualising Museum Collections in Networks', Museum Management and Curatorship, vol 23, no 3, 2008, p232.

${ }^{62}$ Sheila Watson, 2009, Instrumentalism in History Museums: Can it be Justified and Does it Work? (Online). Available: http:// hdl.handle.net/2381/7379 (Accessed 22 August 2011) 